\title{
PENYULUHAN FAKTOR RISIKO TB PARU DI DESA CIKUNIR KECAMATAN SINGAPARNA KABUPATEN TASIKMALAYA TAHUN 2017
}

\section{A. DASAR PEMIKIRAN}

1. Latar Belakang

Tuberkulosis Paru (TB) paru merupakan penyakit kronis dengan agent Mycobacterium tuberculosis yang terus mengalami peningkatan kasus karena penularannya dari droplet penderita melalui udara. World Health Organization (WHO) merumuskan TB sebagai kegawatdaruratan dunia (Global Emergency). Hal ini disebabkan oleh adanya epidemi Human Immunodeficiency Virus/ Acquired Immuno Deficiency Syndrome (HIV/AIDS). Selain itu juga adanya resisten berbagai obat (Depkes, 2009).

Menurut WHO tahun 2011 menyatakan bahwa prevalensi TB paru diperkirakan dengan total penderita adalah 660.000 penderita per tahun, sedangkan insidensi TB paru diestimasikan sebesar 430.000 kasus baru per tahun. Estimasi kematian akibat TB paru di dunia adalah 61.000 kematian per tahunnya.

Berdasarkan laporan tahunan World Health Organization (WHO) disimpulkan bahwa ada 22 negara dengan kategori beban tinggi terhadap TB (high Burden of TBC Number). Sebanyak 8,9 juta penderita TB dengan proporsi $80 \%$ pada 22 negara berkembang dengan kematian 3 juta orang per tahun dan 1 orang dapat terinfeksi TB setiap detik. Indonesia sekarang berada pada ranking kelima negara dengan beban TB tertinggi di dunia (WHO, 2010). Menurut WHO tahun 2014 menyatakan bahwa terdapat
9,6 juta penduduk dunia terinfeksi TB paru.

Berdasarkan laporan Depkes RI tahun 2008 menyatakan bahwa prevalensi TB paru yang paling terbanyak adalah Indonesia bagian timur sebesar 44\%, pada peringkat kedua adalah Indonesia bagian barat yaitu di wilayah Sumatera sebesar 33\%, di wilayah Jawa dan Bali sebesar 23\%. Di provinsi Jawa Barat prevalensi TB paru sebesar $0,7 \%$.

Prevalensi TB paru di Provinsi Jawa Barat terus mengalami kenaikan kasus. Menurut Profil Kesehatan Jawa Barat tahun 2012 menyatakan bahwa Kabupaten Tasikmalaya dengan jumlah kasus TB paru dan diobati sebanyak 1.088 penderita, angka kesembuhan TB paru pada penduduk laki-laki dan perempuan sebanyak 995 penduduk atau sebesar 91,45\%. Angka pengobatan lengkap TB paru pada laki-laki dan perempuan sebanyak 29 orang atau sebesar 2,67 \%, dengan angka kesuksesan (Success Rate/SR) sebesar 94,12 \%. Apabila dilihat dari angka pengobatan lengkap TB paru menunjukkan masih rendahnya kesadaran penderita TB paru dalam melakukan pengobatan lengkap.

Berdasarkan data di bagian Surveilens Epidemiologi Puskesmas Singaparna tercatat ada 71 penderita TB paru pada tahun 2017. Berdasarkan permasalahan tersebut penulis tertarik untuk melakukan pengabdian masyarakat melalui kegiatan penyuluhan Faktor Risiko TB paru. 


\section{B. TUJUAN}

1. Tujuan Umum

a. Penyebarluasan informasi untuk meningkatkan pengetahuan TB paru kepada masyarakat Gunung Kawung tentang faktor-faktor risiko TB paru.

b. Memberikan informasi tentang perilaku berisiko TB paru seperti meludah sembarangan, membuang droplet sembarangan, tidak menggunakan masker, ketidakpatuhan berobat atau drop out yang akan memperlambat kesembuhan TB paru.

c. Meningkatkan pengetahuan dan kesadaran kepada masyarakat Gunung Kawung untuk senantiasa berperilaku hidup bersih dan sehat.

\section{MANFAAT}

Penyuluhan Faktor-faktor risiko TB paru memberikan informasi bagi masyarakat Gunung Kawung tentang definisi TB paru, penyebab, faktor-faktor yang meningkatkan kejadian TB paru, pencegahan TB paru.

\section{BENTUK KEGIATAN}

Bentuk Kegiatan pengabdian masyarakat ini antara lain :

1. Penyuluhan Faktor-faktor Risiko TB paru

2. Tata Cara pemakaian masker dengan Benar

3. Diskusi dengan masyarakat Gunung Kawung tentang TB paru.

E. SASARAN

Masyarakat Gunung Kawung yang menderita TB paru berjumlah 7 Orang.

\section{F. WAKTU}

$\begin{array}{ll}\text { Hari } & : \text { Jumat } \\ \text { Tanggal } & : 19 \text { Maret } 2017 \\ \text { Pukul } & : 11.00-13.00 \text { WIB }\end{array}$

\section{G. KEPANITIAAN}

Pelindung

Ketua STIKes Respati

Ketua Pelaksana :

Wuri Ratna Hidayani, S.K.M., M.Sc

Anggota

mahasiswa kesmas

\section{H. HASIL KEGIATAN}

Dengan hasil sebagai berikut ini :

1. Pemahaman dan pengetahuan tentang faktor-faktor risiko TB paru pada Masyarakat Dusun Gunung Kawung Desa Cikunir Kecamatan Singaparna Kabupaten Tasikmalaya.

2. Pengetahuan tentang faktor-faktor risiko TB paru pada masyarakat dapat meningkat

3. Masyarakat memberikan respon positif terbukti adanya tanya jawab tentang faktor risiko TB paru.

4. Masyarakat bersemangat mengikuti penyuluhan dan diharapkan dapat menghindari faktor risiko TB paru mengaplikasikan pola hidup sehat terutama menggunakan masker ketika kontak dengan orang lain, tidak meludah atau membuang droplet sembarangan. Dapat meningkatkan kepatuhan berobat TB paru di fasilitas kesehatan. 


\section{DOKUMENTASI}

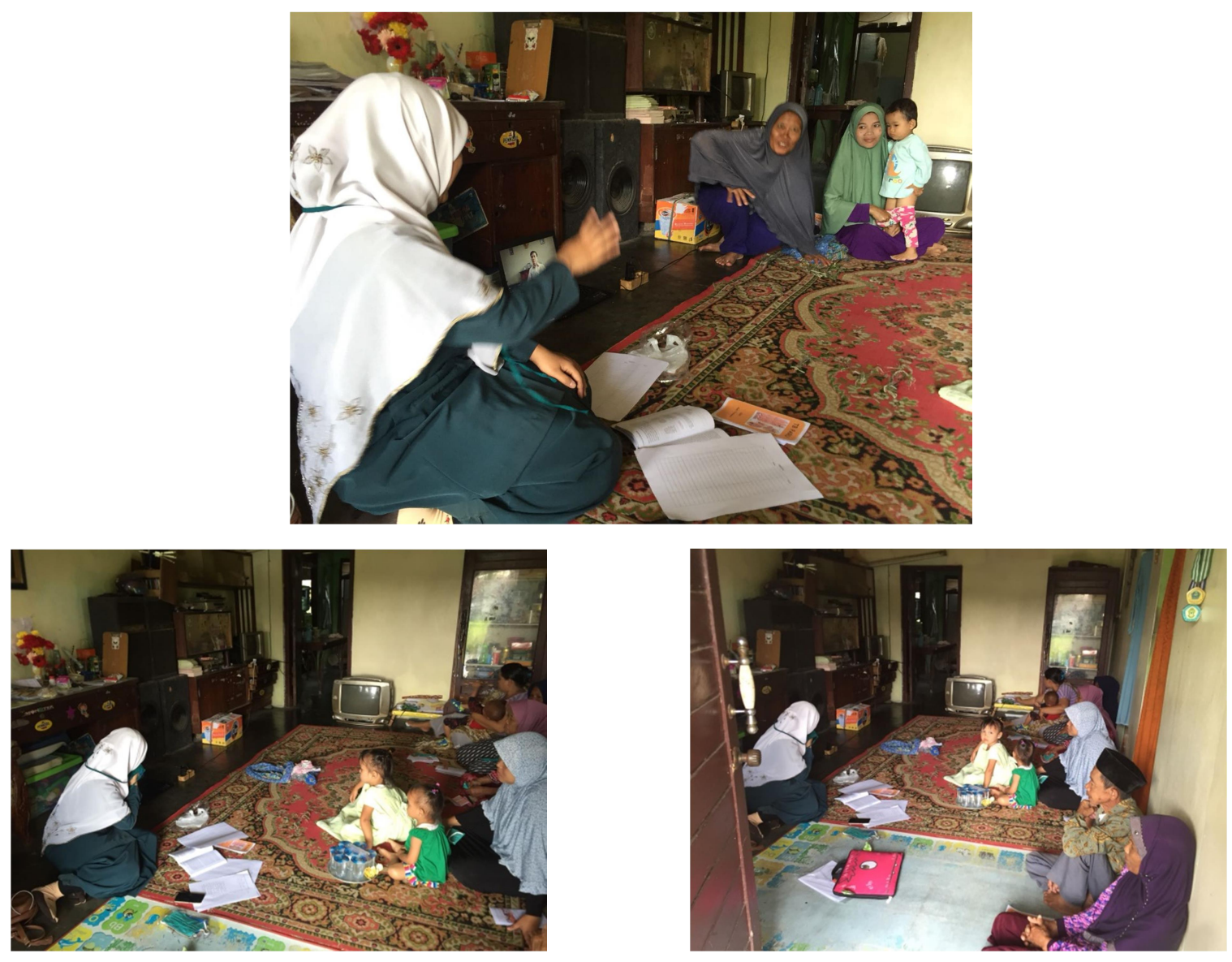

Gambar : Penyuluhan Faktor resiko KB 